\title{
AN ANALYSIS OF COMPRESSIVE STRAIN IN ADJAGENT TEMPERATURE-GRADIENT AND EQUI-TEMPERATURE LAYERS IN A NATURAL SNOW GOVER
}

\author{
By Righard L. Armstrong \\ (Institute of Arctic and Alpine Research, University of Colorado, Boulder, Colorado 8ozog, \\ U.S.A.)
}

\begin{abstract}
Compressive strain-rates in discrete layers of a sub-alpine snow cover are analyzed. Individual layers are identified according to density and the dominant type of metamorphism which contributed to their formation. Data were collected during four winter seasons at the Institute of Arctic and Alpine Research (INSTAAR) snow-study site (3 $400 \mathrm{~m})$, Red Mountain Pass, south-western Colorado, U.S.A. At average densities of less than $250 \mathrm{~kg} \mathrm{~m}^{-3}$ the influence of metamorphism on strain-rate is not apparent. However, at densities greater than $250 \mathrm{~kg} \mathrm{~m}^{-3}$, two separate relationships emerge for strain as a function of crystal type and density. While two adjacent layers may exhibit comparable densities, a layer of sintered, fine grained (ET) snow indicates a strain-rate approximately one order of magnitude greater than an adjacent layer of cohesionless, coarse-grained (TG) snow.

RÉsumé. Une analyse des contraintes de compression dans des couches voisines, l'une à gradient de température, l'autre isotherme dans un manteau neigeux naturel. On analyse les taux de compression dans des couches individuelles d'un manteau neigeux subalpin. Chaque couche est identique par sa densité et le type dominant de métamorphose qui a contribué à sa formation. Les données ont été recueillies pendant quatre saisons d'hiver au champ d'étude de la neige $(3400 \mathrm{~m})$ de l'Institute of Arctic and Alpine Research (INSTAAR) au Red Mountain Pass, Sud Ouest Colorado, U.S.A. A des densités moyennes inférieures à $250 \mathrm{~kg} \mathrm{~m}^{-3} \mathrm{l}^{\prime}$ influence de la métamorphose sur le taux de contrainte n'est pas apparent. Cependant à des densités supérieures à $250 \mathrm{~kg} \mathrm{~m}^{-3}$ deux relations séparées apparaissent selon lesquelles la contrainte est fonction du type des cristaux et de la densité. Alors que deux couches voisines peuvent avoir des densités comparables une couche de neige tassée à grains fins (ET) montre un taux de contrainte approximativement un ordre de grandeur supérieur à celui d'une couche voisine de neige sans cohésion à gros grains (TG).

Zusammenfassung. Eine Analyse der kompressiven Verformung in benachbarten Schichten einer Schneedecke, zwischen denen ein Temperaturgradient bzw. Temperaturgleichheit besteht. Die kompressiven Verformungsraten in getrennten Schichten einer subalpinen Schneedecke werden analysiert. Einzelne Schichten lassen sich nach ihrer Dichte und nach dem Haupttyp der Metamorphose, der zu ihrer Bildung führte, unterscheiden. Beobachtungsdaten wurden in vier Winterperioden an der Schneestudienstelle (3 $400 \mathrm{~m})$ des Institute of Arctic and Alpine Research (INSTAAR) am Red Mountain Pass, Südwest-Colorado, USA, gewonnen. Bei mittleren Dichten von weniger als $250 \mathrm{~kg} \mathrm{~m}^{-3}$ lässt sich kein Einfluss des Metamorphismus auf die Verformungsrate feststellen. Bei Dichten über $250 \mathrm{~kg} \mathrm{~m}^{-3}$ zeigen sich zwei getrennte Abhängigkeiten der Verformung vom Kristalltyp und von der Dichte. Bei nahezu gleicher Dichte in zwei benachbarten Schichten weist die eine, die aus gesintertem, feinkörnigem (ET) Schnee besteht, eine um eine Ordnung grössere Verformungsrate auf als ihre Nachbarschicht aus kohäsionslosem, grobkörnigem (TG) Schnee.
\end{abstract}

\section{INTRODUGTION}

Attempts to formalize density-depth and density-time relationships in natural snow covers have primarily involved the perennial snows of polar regions (Bader, 1963; Kojima, 1964). Similar efforts for dry seasonal alpine snow are complicated by widely varying accumulation rates, considerable temperature ranges, and the effects of metamorphism and grain-size. Keeler ( 1967 ) noted in his studies that densification did not appear to be affected by temperature in the range $-\mathrm{I}$ to $-10^{\circ} \mathrm{C}$ but was inversely proportional to grain size and sensitive to rates of loading, especially during the formative stage of any particular snow layer. Kojima ([1975]) observed the relation between strain-rate of densification and compressive stress by subjecting a natural snow cover to specific load increments. It was found that the strain-rate of a snow layer is approximately proportional to the load but the coefficient of proportionality decreases exponentially as the density of layer increases. Densities involved in the study ranged from 100 to $300 \mathrm{~kg} \mathrm{~m}^{-3}$ with mean snow temperatures between -3.1 and $-8.7^{\circ} \mathrm{C}$. It was concluded that under these conditions natural densification of a snow cover is determined primarily by the load, and not by metamorphism of the snow grains. Bergen (1978) noted that in a dry, annual snow-cover settlement is a strong function of rate of loading, 
thermal regime, and sample density. While this study primarily involved fine-grained snow (grain sizes in the vicinity of $1.0 \mathrm{~mm}$ ) the author did note an apparent tendency for viscosity to increase with grain-size.

\section{INFLUENGE OF METAMORPHISM ON DENSIFICATION}

The following study focuses on the role of metamorphism and associated grain size in the densification-compressive load relationship. Systematic field measurements of changes in snow-layer density with time have allowed a preliminary distinction between two densification patterns as a function of metamorphic regime. Temperature-gradient (TG) layers (Sommerfeld and LaChapelle, 1970) appear to densify at the same rate as those exposed to lesser temperature gradients while in the $100-200 \mathrm{~kg} \mathrm{~m}^{-3}$ density range but then densification appears to diminish and the curves become asymptotic at approximately $250 \mathrm{~kg} \mathrm{~m}^{-3}$. The non-TG layers continue to densify as an apparent function of load and time with the curves becoming asymptotic at approximately $400 \mathrm{~kg} \mathrm{~m}^{-3}$ (see Fig. I). The numbered curves represent data from one annual snow cover (1972-73) which developed in the general absence of a significant temperature gradient. The numerical progression is from the oldest to the youngest layer and the relative location of the curves after an elapsed time of i $50 \mathrm{~d}$ may simply be interpreted as a function of increasing overburden pressure with depth. Generally, total overburden increased from $\mathrm{I}$ to $50 \mathrm{~g} \mathrm{~cm}^{-2}$ during the time period shown. Grain diameters averaged less than 1.o mm. The TG curve is typical of the basal "depth-hoar" layers observed in this study where grain diameter averages are $2-4 \mathrm{~mm}$.

While it may be considered somewhat speculative to distinguish between TG and equitemperature (ET) (Sommerfeld and LaChapelle, 1970) snow layers during early stages of formation, the physical properties exhibited by mature examples of each type are clearly identifiable. Figure 2 shows an example of snow structure typical of a continental climate during mid-winter. The discontinuity in density and ram resistance values at $60 \mathrm{~cm}$ is attributed to the sharp boundary between mature TG and ET snow.

What were the physical conditions which produced this discontinuity and how do the mechanical properties of the two snow types differ? In order to describe the evolution of these two layers we must go back in time and trace their development in terms of the prevailing temperature, density, overburden, and strength record.

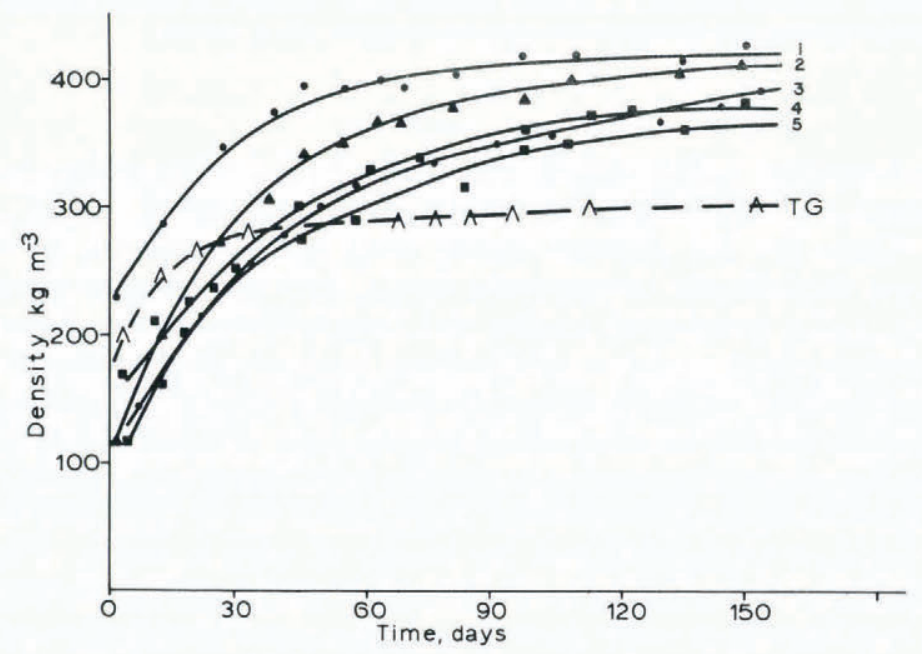

Fig. $\boldsymbol{I}$. Change in density with time for individual $5.0 \mathrm{~cm}$ snow layers. Data are from standard snow-pit studies at the INST AAR snow-study site, Red Mountain Pass, Colorado (3 $400 \mathrm{~m})$. 


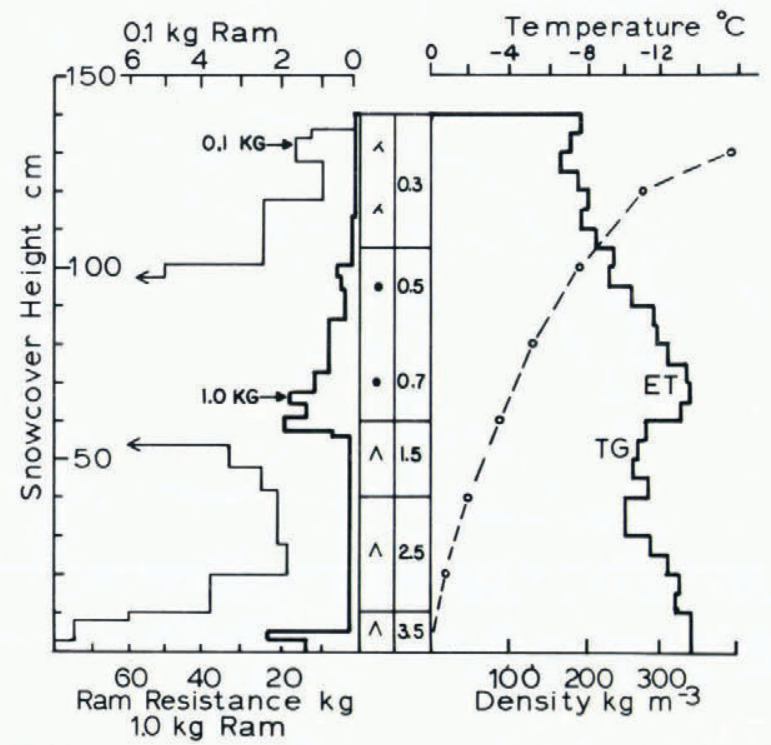

Fig. 2. Snow-pit data, INST AAR snow-study site, I6 January $1975, \mathrm{I} .0 \mathrm{~kg}$ data $=$ standard ram penetrometer; $0 . \mathrm{I} \mathrm{kg}=$ data from light-weight ram with standard cone dimensions and weight of $0.1 \mathrm{~kg}$.

\section{Physical distinction Between TG AND ET Layers}

Figure 3 traces changes in density and ram resistance for the TG and ET layers of Figure 2. The discontinuity in late April is a result of the presence of free water in the snow layers. Figures 4 and 5 trace the vapor-pressure-gradient history of the two layers. Vapor-pressure values were calculated from measured temperature data according to the Goff-Gratch formulation for plane ice surfaces (List, r 949). The difference between these values and those associated with the micro-relief of the snow grains is not considered significant with respect to the scale of this study. Investigations into the relationship between vapor pressure and TG recrystallization with time (LaChapelle and Armstrong, 1977) indicate that at gradients less than approximately $0.07-0.05 \mathrm{mbar}^{-1} \mathrm{~cm}^{-1}$ the TG recrystallization may no longer be the dominant metamorphic mode. Figure 6 contains curves which describe this relationship with respect to three stages of advancement of TG metamorphism. These data were obtained in the following manner. At sites receiving minimal direct solar radiation, the existing snow cover was removed just prior to a new snow accumulation. The resulting shallow, usually $20-50 \mathrm{~cm}$ thick, layers of new snow were monitored at least once per day with respect to temperature gradient and crystal morphology. Sample densities were generally in the range 50-150 $\mathrm{kg} \mathrm{m}^{-3}$. Similar tests were conducted in a cold lab and a comparable vapor pressure threshold for TG metamorphism was obtained. Each point on the curves indicated by the crystal-type symbol is the mean of several observations. Error bars are one standard deviation.

Returning to Figure 4, it is apparent that the TG layer remains at or above an average vapor pressure of $0.05 \mathrm{mbar}^{-1} \mathrm{~cm}^{-1}$ for approximately $60 \mathrm{~d}$ while the layer which is ultimately identified as ET (Fig. 5) experiences such a vapor-pressure regime for the initial few days only. In summary, whether a given new-snow layer evolves into a readily identifiable ET or TG layer is determined primarily by vapor-pressure gradient, void space, and overburden. Voidspace ratio is high in any new-snow layer, allowing optimal vapor flux. Rates of loading due to new-snow layers in a continental climate are generally small, 0.1 to $10.0 \mathrm{~g} \mathrm{~cm}^{-2} \mathrm{~d}^{-1}$. Once a given metamorphic regime is established, a positive feed-back mechanism results which tends to maintain the initial regime. TG snow appears to resist settlement, thus porosity is 


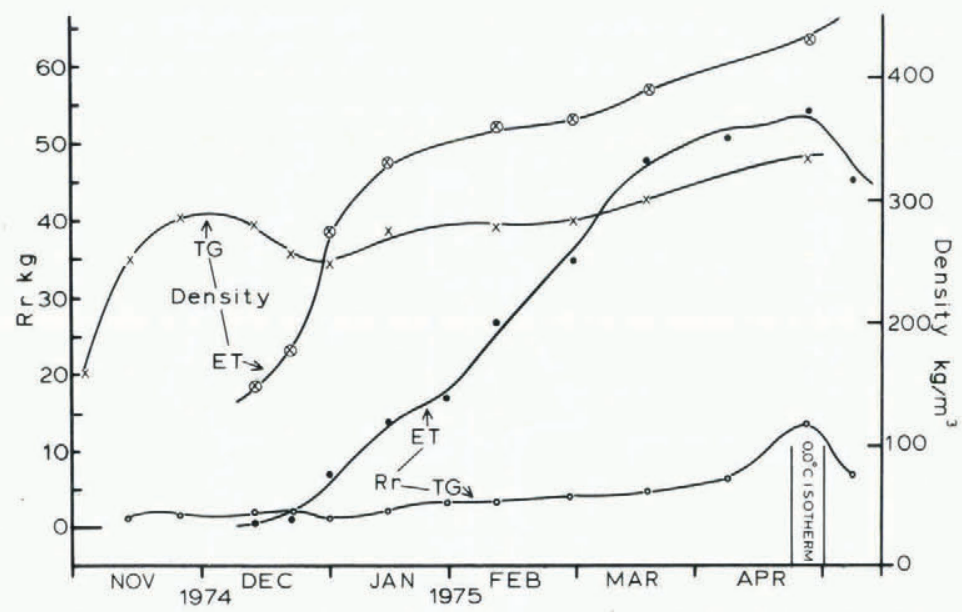

Fig. 3. Change in mean density and ram resistance $(R r)$ with time for well-defined $T G$ and $E T$ snow layers. The layers extend approximately $20 \mathrm{~cm}$ above $(E T)$ and $20 \mathrm{~cm}$ below $(T G)$ the discontinuity in Figure 2.

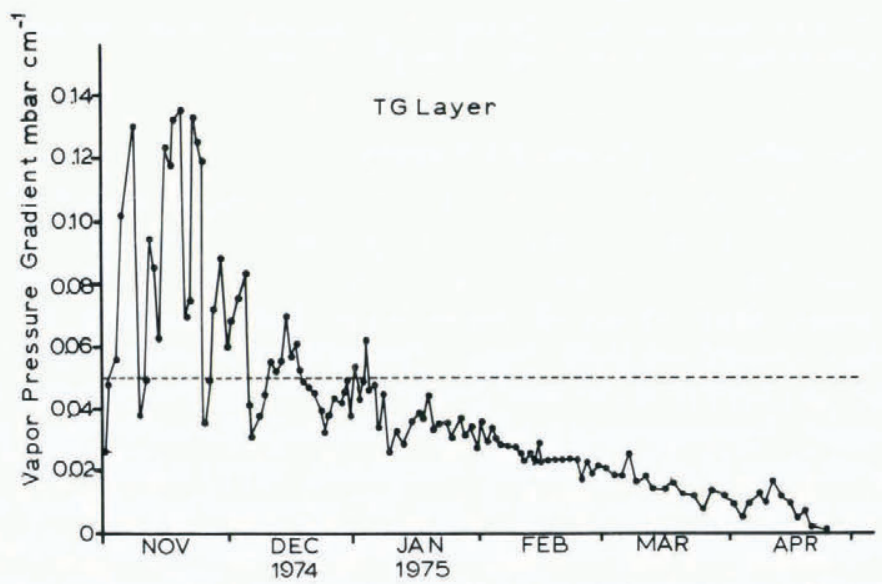

Fig. 4. Change in saturation vapor-pressure gradient (calculated) with time within the TG layer of Figure 2.

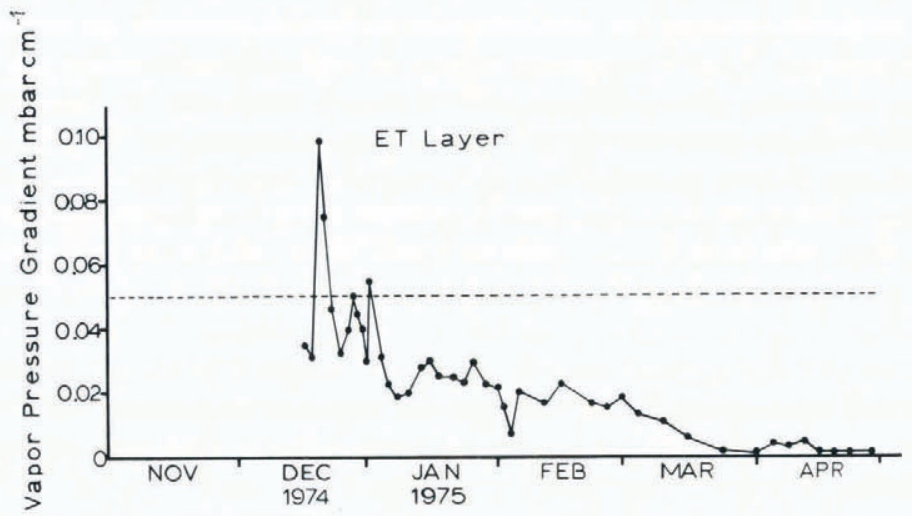

Fig. 5. Change in saturation vapor-pressure gradient (calculated) with time within the ET layer of Figure 2. 


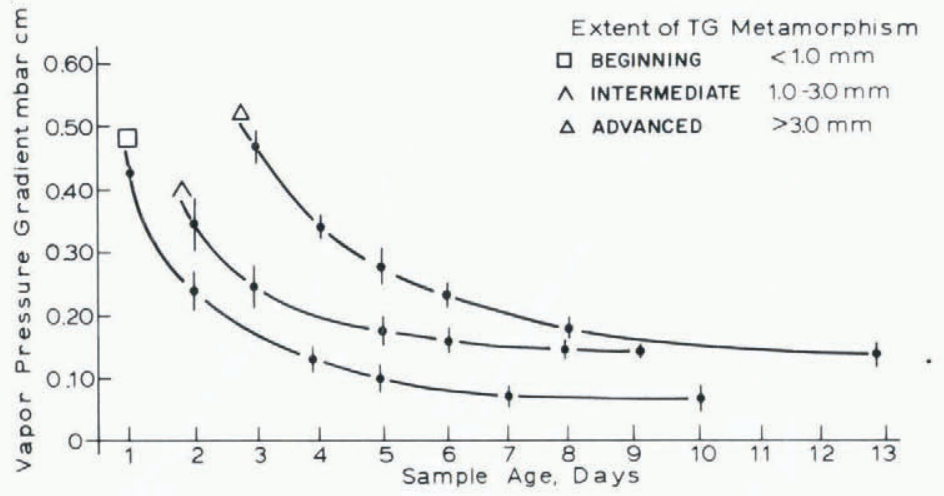

Fig. 6. The degree of recrystallization (TG metamorphism) within layers of new snow accumulating under natural conditions on bare ground as a function of saturation vapor-pressure gradient and time. Each data point is the mean of several observations. Error bars $=$ one standard deviation. A total of $4^{8}$ observations were made over two winters.

maintained, allowing optimal vapor flux, and TG metamorphism persists as long as an appropriate vapor-pressure gradient is maintained. In contrast, once a layer of new snow is allowed to densify significantly, decreased permeability will retard vapor flux and supress TG metamorphism with resulting settlement causing void space to be further diminished. Once a shallow layer of snow such as that represented in Figure 4 has reached a mature stage of TG recrystallization, density generally appears to remain constant or increase only slightly, even after the initial vapor-pressure gradient is diminished and the load of subsequent snow-falls accumulates above. In contrast, the layer represented by Figure 5 develops a well-settled, fine-grained, cohesive structure (ET metamorphism) in the absence of a significant vaporpressure gradient. Thus, the controlling parameters for the sharp discontinuity have been identified.

\section{Results}

Results of this study are in agreement with other work which emphasizes the role of compressive load in densification of low-density snow. In Figure $\mathrm{I}$ the initial segments (first 20 days) of the densification curves do not vary as any apparent function of metamorphic mode. However, it is what occurs after density has exceeded $200-225 \mathrm{~kg} \mathrm{~m}^{-3}$ that is of specific interest here. Figure 7 describes compressive strain as a function of layer density at a level site. Two distinct linear relationships emerge controlled by type of metamorphism. Data are taken from three different winter seasons when significant "depth-hoar" layers developed at the base of the snow cover. Strain-rates are calculated from differential vertical movement of platters on a resistance (nichrome) wire settlement gauge of the type similar in design to those described elsewhere (Keeler, 1969). Data were taken from those layers just above and below the incipient discontinuity averaging $20-30 \mathrm{~cm}$ in thickness at the time of initial measurement. Density values for snow layers bounded by settlement platters were obtained via a gammaradiation profiling snow-density gauge (Armstrong and Ives, 1976) and were checked against density measurements using standard $500 \mathrm{~cm}^{-3}$ SIPRE snow tubes at seven-day intervals. Each data point represents a mean value (density and vertical strain) for a five-day period. At strain-rates greater than about $5 \times 10^{-3} \mathrm{~d}^{-1}$ scatter in the data began to increase significantly due to the fact that at lower densities metamorphism exerts a diminishing influence. In the density range represented in Figure 7, the influence of the load of new snow increments would be minimal (Kojima, [1975]) and the metamorphosed layers involved lie at depths sufficient 


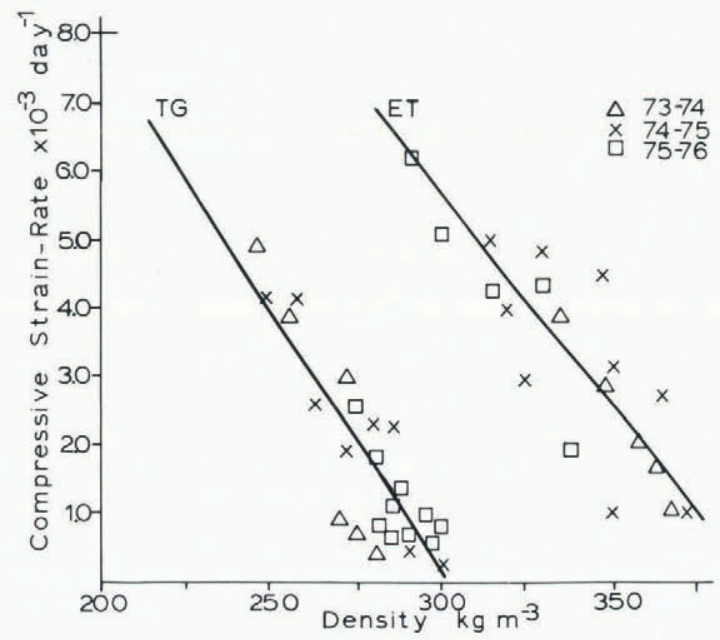

Fig. 7. Relationship between compressive strain-rate and density for TG and ET snow layers. Each data point is a five-day mean value for both density and strain-rate. Data are from three winter seasons. The coefficient of determination $r$, the regression line, and the standard error of the estimate of $y$ on $x, S_{y x}$, for the TG and ET curves are: For TG$r^{2}=0.713^{8}, y=23.421-0.077, S_{y x}=0.763 ;$ For ET $-r^{2}=0.7434, y=23.586-0.059, S_{y x}=0.899$.

to eliminate the effect of diurnal temperature variations. The average temperature range for the layers represented in Figure 7 was -1.0 to $-5.0^{\circ} \mathrm{C}$. Therefore, crystal type becomes the primary factor influencing strain-rate.

As two adjacent TG and ET snow layers densify under conditions described here, the diminishing vertical strain-rate of the TG layer allows the younger ET layer to equal and eventually exceed the density of the TG layer below. For example, this occurs in late December in Figure 3. In general this cross-over appeared at a density of approximately $280-300 \mathrm{~kg} \mathrm{~m}^{-3}$ in the natural snow samples of this study. At this point, therefore, two adjacent snow layers may possess similar average densities but the fine-grained layer (ET) is straining at approximately ten times the rate of the TG layer. During late December or early January, when the TG and ET layers were approaching equal densities, typical overburden pressures were in the range 5 to $15 \mathrm{~g} \mathrm{~cm}^{-2}$. At low stresses, compressive viscosity $\eta$ has been assumed to be an expression of the linear relationship between stress $\sigma$ and strain-rate $\epsilon$,

$$
\eta=\sigma / \epsilon
$$

(Mellor and Smith, I 966). When this relationship is applied to the two layer types while they exist at similar densities, $\eta$ for ET layers was on the order of $10^{7} \mathrm{~g} \mathrm{~cm}^{-2} \mathrm{~s}^{-1}$ while for the TG layers, $\eta$ was $10^{9} \mathrm{~g} \mathrm{~cm}^{-2} \mathrm{~s}^{-1}$. In general these values are in the range described by Keeler (1967) for alpine snow covers.

\section{Conclusion}

In a dry, sub-alpine snow cover with thickness and average density appropriate to a highaltitude continental climate, dramatic discontinuities often appear in stratigraphic profiles. Perhaps the most obvious appears at the upper boundary of a mature basal TG (depth-hoar) layer. The formation of thick depth-hoar layers $(30-60 \mathrm{~cm})$ is defined here by recrystallization of available mass along vapor-pressure gradients to ultimately achieve a structure that inhibits settlement. The large difference in density exhibited by adjacent TG and ET layers is explained here by different strain-rates, rather than by any significant mass flux across the 
discontinuity. The TG layer achieves its unique characteristics due to minimal densification and a "grain-to-grain" recrystallization rather than by net mass loss to the layers above.

Results from this study indicate that by late December or early January, the snow layers above and below this discontinuity densify as a function of crystal type with temperature and overburden being of lesser importance. In the density range $280-300 \mathrm{~kg} \mathrm{~m}^{-3}$ the compressive strain in a coarse-grained (TG) layer is about one order of magnitude less than the rate indicated by the fine grained (ET) layer above. Grain sizes are generally $>2.0 \mathrm{~mm}$ and $<$ I.o $\mathrm{mm}$ respectively.

\section{Acknowledgements}

Support during the collection of field data analyzed in this study has been provided by U.S. Army Research Office and Department of the Interior, Bureau of Reclamation. The author gratefully acknowledges the guidance and suggestions provided by Dr E. R. LaChapelle, particularly in the work describing the relationship between vapor-pressure gradient and "depth-hoar" formation. I also wish to express my appreciation to Dr M. Mellor for his continuous assistance and encouragement in the effort to distill concise information from broad-scale field measurements. Thanks go to numerous field observers who were involved in the collection of the raw data comprising this study, with specific acknowledgement of the technical assistance provided by Dr T. Carroll and W. McClelland.

\section{REFERENCES}

Armstrong, R. L., and Ives, J. D., ed. 1976. Avalanche release and snow characteristics, San Juan Mountains, Colorado. University of Colorado. Institute of Arctic and Alpine Research. Occasional Paper No. I9.

Bader, H. 1963. Theory of densification of dry snow on high polar glaciers. II. (In Kingery, W. D., ed. Ice and snow; properties, processes, and applications: proceedings of a conference held at the Massachusetts Institute of Technology, February ${ }_{12-16}{ }_{1962}$. Cambridge, Mass., M.I.T. Press, p. $35^{1-76 .)}$

Bergen, J. D. 1978. Some measurements of settlement in a Rocky Mountains snow cover. Fournal of Glaciology, Vol. 20 , No. 82 , p. $141-48$.

Keeler, C. M. 1967. Some observations on the densification of alpine snow cover. U.S. Cold Regions Research and Engineering Laboratory. Technical Report 197.

Keeler, C. M. 1969. Some physical properties of alpine snow. U.S. Cold Regions Research and Engineering Laboratory. Research Report 27 I.

Kojima, K. 1964. Densification of snow in Antarctica. (In Mellor, M., ed. Antarctic snow and ice studies. Washington, D.C., American Geophysical Union, p. 157-2 r 8. (Antarctic Research Series, Vol. 2.))

Kojima, K. [1975.] A field experiment on the rate of densification of natural snow layers under low stresses. [Union Géodésique et Géophysique Internationale. Association Internationale des Sciences Hydrologiques. Commission des Neiges et Glaces.] Symposium. Mécanique de la neige. Actes du colloque de Grindelwald, avril 1974, p. $298-308$. (IAHS-AISH Publication No. 1 I4.)

LaChapelle, E. R., and Armstrong, R. L. 1977. Temperature patterns in an alpine snow cover and their influence on snow metamorphism. Technical report. [Silverton, Colorado], University of Colorado. Institute of Arctic and Alpine Research.

List, R. J. 1949. Smithsonian meteorological tables. Sixth revised edition. Smithsonian Miscellaneous Collections, Vol. I14. (Smithsonian Publication 4014.)

Mellor, M., and Smith, J. H. 1966. Creep of snow and ice. U.S. Cold Regions Research and Engineering Laboratory. Research Report 220.

Sommerfeld, R. A., and LaChapelle, E. R. 1970. The classification of snow metamorphism. Journal of Glaciology, Vol. 9, No. 55, p. $3^{-17}$. 